\title{
A serosurvey for hantavirus infection in wild rodents from the states of Rio de Janeiro and Pernambuco, Brazil
}

\author{
M. Sobreira ${ }^{\mathrm{a}, *}$, G.T. Souza ${ }^{\mathrm{a}}$, M.L. Moreli ${ }^{\mathrm{b}}$, A.A. Borges ${ }^{\mathrm{c}}$, F.A. Morais ${ }^{\mathrm{d}}$, L.T.M. Figueiredo ${ }^{\mathrm{c}}$, A.M.P. Almeida ${ }^{\mathrm{a}}$ \\ a Departamento de Microbiologia, Centro de Pesquisas Aggeu Magalhães, Recife, PE, Brazil

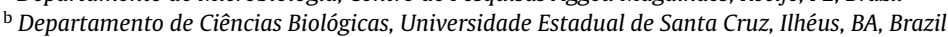

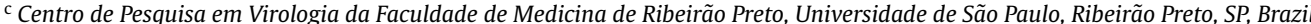 \\ ${ }^{\mathrm{d}}$ Instituto de Ciências Biomédicas, Departamento de Microbiologia, Laboratório de Virologia Clínica e Molecular, Universidade de São Paulo, São Paulo, SP, Brazil
}

\section{A R T I C L E I N F O}

\section{Article history:}

Received 11 June 2007

Received in revised form 19 May 2008

Accepted 22 May 2008

Available online 29 May 2008

\section{Keywords:}

Hantaviruses

Plague

Rodents

\begin{abstract}
A B S T R A C T
Sera from 269 rodents obtained during the routine surveillance operations in plague areas of Rio de Janeiro and Pernambuco states, Brazil were tested by ELISA for specific IgG antibodies against a recombinant nucleocapsid $(\mathrm{N})$ protein of Araraquara hantavirus. ELISA-positive sera were submitted to reverse transcriptase-polymerase chain reaction (RT-PCR) for amplification of the virus genome and later sequencing for identification of the viral variant. The samples from the state of Pernambuco were antibody negative, and although four from Rio de Janeiro were ELISA-positive, they failed to yield viral cDNA by RT-PCR. This is the first report of the presence of antibodies to a hantavirus among rodents from Rio de Janeiro and suggests the possibility of human cases of hantavirus pulmonary syndrome (HPS) in that state, although no case has yet been reported.
\end{abstract}

(c) 2008 Elsevier B.V. All rights reserved.

\section{Introduction}

Hantavirus pulmonary syndrome (HPS) is a severe disease that causes respiratory failure, shock and high mortality. Human infection is acquired by the inhalation of aerosols containing excreta of rodents infected with a hantavirus (Zeier et al., 2005).

HPS and plague are rodent-borne zoonotic diseases, which despite differences in etiology (plague is caused by the bacterium Yersinia pestis), they have similar rodent reservoirs and worldwide distribution (Perry and Fetherston, 1997; Zeier et al., 2005; Gage and Kosoy, 2005). However, the occurrence of HPS and plague has never been detected in the same area of Brazil. Y. pestis circulates among several foci located in the Brazilian regions of the Northeast (Ceará, Rio Grande do Norte, Paraíba, Pernambuco, Alagoas and Bahia) and Southeast (Rio de Janeiro and north of Minas Gerais) (Almeida et al., 1995), while hantaviruses are mostly described in the South and Southeast regions.

International health regulations require continuous surveillance of plague areas to implement prevention measures against human infection in at-risk areas (WHO, 2006). Plague surveillance in Brazil includes the trapping of rodents in the endemic areas to obtain

\footnotetext{
* Corresponding author at: Centro de Pesquisas Aggeu Magalhães, Campus da UFPE, Cidade Universitária, 50670-420 Recife, PE, Brazil. Tel.: +55 81 21012633; fax: +558134532448 .

E-mail address: marise@cpqam.fiocruz.br (M. Sobreira).
}

tissue samples and fleas for the search of the plague bacillus among the rodent hosts and flea vectors and specific antibodies among the rodent hosts (Almeida et al., 1995).

The present study was conducted to investigate the serological evidence of hantavirus infection, as well as to identify the viral variant through reverse transcriptase-polymerase chain reaction (RT-PCR) and sequencing, in rodents captured in plague areas of Rio de Janeiro and Pernambuco states of Brazil.

\section{Materials and methods}

A total of 269 rodent sera obtained during the routine operations of the Brazilian plague surveillance program and maintained in the serum collection of the Centro de Pesquisas Aggeu Magalhães, were analyzed to detect antibodies against hantaviruses.

The sera were tested for hantavirus-specific IgG antibodies by ELISA, using as antigen a recombinant nucleocapsid $(\mathrm{N})$ protein of Araraquara hantavirus produced in the Faculdade de Medicina de Ribeirão Preto da Universidade de São Paulo. The negative antigen was an extract of $E$. coli BL21 Star ${ }^{\mathrm{TM}}$ DE3 One Shot (Invitrogen, USA). Briefly, $50 \mu \mathrm{l}$ of $1: 100$ diluted sera in phosphate-buffered saline (PBS), pH 7.4, 0.1\% Tween 20 (PBST) containing 10\% skim milk, were added to each well of 96-well polystyrene microtiter plates (Greiner bio-one, Germany) coated with the $\mathrm{N}$ protein or the negative antigen and incubated at $37^{\circ} \mathrm{C}$ for $1 \mathrm{~h}$. After 6 cycles of washing with PBST, $50 \mu$ l of a mixture $(v / v)$ of a goat anti-rat IgG and goat anti-Peromyscus leucopus IgG horseradish peroxidase 
Table 1

Rodents from the counties of Nova Friburgo, Sumidouro and Teresópolis tested and positive for antibodies against hantavirus by IgG ELISA

\begin{tabular}{|c|c|c|c|c|c|c|c|}
\hline \multirow[t]{3}{*}{ Species } & \multirow[t]{3}{*}{ Total } & \multicolumn{6}{|l|}{ Origin } \\
\hline & & \multicolumn{2}{|c|}{ Nova Friburgo } & \multicolumn{2}{|c|}{ Sumidouro } & \multicolumn{2}{|c|}{ Teresópolis } \\
\hline & & Tested & Positive (titer) & Tested & Positive (titer) & Tested & Positive (titer) \\
\hline Akodon cursor & 26 & 15 & $1(1: 400)$ & 0 & 0 & 11 & 0 \\
\hline Oligoryzomys nigripes & 12 & 9 & $1(1: 400)$ & 1 & $1(1: 400)$ & 2 & $1(1: 400)$ \\
\hline Oxymycterus judex & 5 & 5 & 0 & 0 & 0 & 0 & 0 \\
\hline Nectomys squamipes & 4 & 2 & 0 & 1 & 0 & 1 & 0 \\
\hline Oryzomys ratticeps & 4 & 0 & 0 & 0 & 0 & 4 & 0 \\
\hline Total & 51 & 31 & 2 & 2 & 1 & 18 & 1 \\
\hline
\end{tabular}

conjugate (Sigma) diluted at 1:2000 in PBST were added, and the plates were incubated at $37^{\circ} \mathrm{C}$ for $1 \mathrm{~h}$. After six washes in PBST, the substrate reagent $O$-phenylenediamine (OPD, Sigma) diluted in citrate-phosphate buffer, $\mathrm{pH}$ 5.0, and $\mathrm{H}_{2} \mathrm{O}_{2}$ according to the manufacturer's instructions was added, and the reaction was allowed to take place in the dark at $37^{\circ} \mathrm{C}$ for $15 \mathrm{~min}$. The reaction was stopped by the addition of $1 \mathrm{~N} \mathrm{HCl}$. Optical densities (OD) were measured in a microplate reader (EMAX, Molecular Devices Corporation, USA) at $490 \mathrm{~nm}$. The adjusted OD of a serum antigen reaction was the OD of the well coated with the $\mathrm{N}$ protein minus the OD of the well coated with the negative antigen. The cut off was the mean of the ODs of the duplicates of each sample plus 3 standard deviations. Samples with an OD higher than the cut off were categorized reagents. Reagent samples were serially diluted fourfold (1/100; $1 / 400 ; 1 / 1600 ; 1 / 6400)$ and retested to determine the antibody titer.

ELISA-positive sera were submitted to RT-PCR as described by Moreli et al. (2004), with minor modifications, for amplification of the virus genome and later sequencing for identification of the viral variant. A positive control (Rio Mamoré hantavirus) and a negative control were used.

\section{Results}

Serum samples from 218 rodents captured in the county of Triunfo, Pernambuco State, during the years 2000, 2004 and 2005: 120 Necromys lasiurus (Bolomys lasiurus), 87 Oryzomys subflavus, 1 Calomys expulsus (Calomys callosus), 9 Oligoryzomys nigripes, and 1 Trichomys apereoides were assayed. All of them were found to be negative for hantavirus antibodies.

Out of 51 samples from rodents captured in Nova Friburgo, Teresópolis and Sumidouro counties in Rio de Janeiro State, during the year 2001, four showed antibodies to a hantavirus: three $O$. nigripes and one Akodon cursor. Table 1 shows the distribution of the rodents examined and positives per origin (county) and their respective antibody titers. Hantavirus genome was not amplified by RT-PCR from RNA extracted from ELISA-positive samples.

\section{Discussion}

In Brazil, hantaviruses have been mostly described in the South and Southeast, and plague occurs mostly in the Northeast where studies of hantaviruses are lacking. So far, most studies on hantaviruses in Brazil have been limited to animals trapped close to areas where HPS occurred (Romano-Lieber et al., 2001; Katz et al., 2001; Suzuki et al., 2004; Rosa et al., 2005). Only a few serosurveys have been carried out in rodents from areas without confirmed human HPS cases (Lemos et al., 2004; Oliveira et al., 2004). The presence of antibodies to hantaviruses has been detected in $N$. lasiurus (B. lasiurus), A. cursor, O. nigripes and Holochilus sciureus. N. lasiurus (B. lasiurus) and $A$. cursor were associated with Araraquara virus and $O$. nigripes with Juquitiba virus in Southeast and South Brazil, respectively (Suzuki et al., 2004; Figueiredo, 2006). More recently, two new hantaviruses have been recognized associated with the rodents $H$. sciureus (Rio Mearim virus) and Oligoryzomys fornesi (Anajatuba virus) in the northern Brazil (Rosa et al., 2005) and two others with humans, Araucária in the state of Parana (Raboni et al., 2005) and Paranoa in Brasilia the Federal District (GenBank accession no. EF576661.1).

At present, no human case of HPS has yet been recorded in the states of Pernambuco and Rio de Janeiro. Our study shows for the first time the presence of antibodies to one or more hantaviruses among rodents from Rio de Janeiro. These results may be underestimates because the samples examined were stored for prolonged periods, from 1 month to 5 years, at $-20^{\circ} \mathrm{C}$, and had been frozen and thawed several times, which could be deleterious to the titers. However, in some cases their prevalences are quite high (up to $100 \%$ for 0 . nigripes from Sumidouro).

Viral genome was not amplified from ELISA-positive samples from Rio de Janeiro. This could be attributed to the storage conditions of the samples. On the other hand, Moreli et al. (2004) reported that samples frozen and thawed could be suitable for hantavirus genome detection by RT-PCR.

The failure to amplify the genome of the virus could also be due to the lack of adequate levels of viremia in infected specimens. Experimental studies with hantaviruses have shown that viremia can be rather transient after infection and that viral RNA titers do not reach high levels (Botten et al., 2000; Romano-Lieber et al., 2001; Lemos et al., 2004).

Although no human case has yet been reported in the state of Rio de Janeiro, the serological evidence of infection among rodents suggests hantavirus circulation and the possibility of human cases of HPS. Further studies are necessary to better understand the situation of hantavirus infection in rodents of Rio de Janeiro.

The absence of ELISA-positive rodents in Triunfo in the state of Pernambuco cannot rule out infection for the entire state. Furthermore, two known reservoir species had sample sizes of only nine (O. nigripes) and one (C. expulsus), far too few to rule out infection.

On the other hand, it is curious that a large sample of $N$. lasiurus (B. lasiurus) analyzed (120) showed no evidence of infection with Araraquara virus. N. lasiurus (B. lasiurus) is the reservoir for Araraquara virus, and with a few exceptions hantaviruses seem to be distributed throughout the range of their hosts. This finding suggests the possibility that the $N$. lasiurus from Pernambuco might be genetically different from those that support infection with Araraquara virus. Studies on a larger rodent sample size from other areas from the state of Pernambuco are needed.

\section{Acknowledgments}

We thank the Conselho Nacional de Desenvolvimento Científico e Tecnológico (CNPq) for financial support (Process No 401552/2004-Ed 392004) and Dr. A. Leyva for carefully reviewing the manuscript. Voucher specimens of rodents are deposited 
in the Mammalian Collection of the Universidade Federal de Pernambuco, Recife, PE, Brazil.

\section{References}

Almeida, A.M.P., Leal, N.C., Carvalho, F., Sobrinho, J.D., Almeida, C.R., 1995. Plague surveillance in Brazil: 1983-1992. Rev. Inst. Med. Trop. São Paulo 37, 511-516.

Botten, J., Mirowsky, K., Kusewitt, D., Bharadwaj, M., Tee, J., Ricci, R., Feddersen, R.M., Hjelle, B., 2000. Experimental infection model for Sin Nombre hantavirus in the deer mouse (Peromyscus maniculatus). Proc. Natl. Acad. Sci. (Wash.) 97, 10578-10583.

Figueiredo, L.T.M., 2006. Febres hemorrágicas por vírus no Brasil. Rev. Soc. Bras. Med. Trop. 39, 203-210.

Gage, K.L., Kosoy, M.Y., 2005. Natural history of plague: perspectives from more than a century of research. Ann. Rev. Ent. 50, 505-528.

Katz, G., Williams, R.J., Burt, M.S., de Souza, L.T., Pereira, L.E., Mills, J.N., Suzuki, A., Ferreira, I.B., Souza, R.P., Alves, V.A., Bravo, J.S., Yates, T.L., Meyer, R., Shieh, W., Ksiazek, T.G., Zaki, S.R., Khan, A.S., Peters, C.J., 2001. Hantavirus pulmonary syndrome in the State of São Paulo, Brazil, 1993-1998. Vect. Born. Zoon. Dis. 1, 181-190.

Lemos, E.R., D’Andrea, P.S., Bonvicino, C.R., Famadas, K.M., Padula, P., Cavalcanti, A.A., Schatzmayr, H.G., 2004. Evidence of hantavirus infection in wild rodents captured in a rural area of the state of São Paulo. Brazil. Pesq. Vet. Bras. 24, 7173.

Moreli, M.L., Sousa, R.L., Figueiredo, L.T.M., 2004. Detection of Brazilian hantavirus by reverse transcription polymerase chain reaction amplification of $\mathrm{N}$ gene in patients with hantavirus cardiopulmonary syndrome. Mem. Inst. Oswaldo Cruz. 99, 633-638.

Oliveira, R.C., Rozental, T., Alves-Correa, A.A., D’Andrea, P.S., Schatzmayr, H.G. Cerqueira, R., Lemos, E.R.S., 2004. Study of hantavirus infection in captive breed colonies of wild rodents. Mem. Inst. Oswaldo Cruz. 99, 575-576.

Perry, R.D., Fetherston, J.D., 1997. Yersinia pestis-etiologic agent of plague. Clin. Microbiol. Rev. 10, 35-66.

Raboni, S.M., Rubio, G., De Borba, L., Zeferino, A., Skraba, S.G., Santos, C.N.D., 2005 Clinical survey of hantavirus in southern Brazil and the development of specific molecular diagnosis tools. Am. J. Trop. Med. Hyg. 72, 800-804.

Romano-Lieber, N.S., Yee, J., Hjelle, B., 2001. Serologic survey for hantavirus infections among wild animals in rural areas of São Paulo State. Brazil. Rev. Inst. Med. Trop. São Paulo 43, 325-327.

Rosa, E.S., Mills, J.N., Padula, P.J., Elkhoury, M.R., Ksiazek, T.G., Mendes, W.S., Santos, D., Araujo, G.C., Martinez, V.P., Rosa, J.F., Edelstein, A., Vasconcelos, P.F. 2005. Newly recognized hantaviruses associated with hantavirus pulmonary syndrome in northern Brazil: partial genetic characterization of viruses and serologic implication of likely reservoirs. Vect. Born. Zoon. Dis. 5, 11-19.

Suzuki, A., Bisordi, I., Levis, S., Garcia, J., Pereira, L.E., Souza, R.P., Sugahara, T.K., Pini, N., Enria, D., Souza, L.T., 2004. Identifying rodent hantavirus reservoirs. Brazil. Emerg. Infect. Dis. 10, 2127-2134.

WHO, 2006. International meeting on preventing and controlling plague: the old calamity still has a future. Wkly. Epidemiol. Rec. 28, 278-284.

Zeier, M., Handermann, M., Bahr, U., Rensch, B., Muller, S., Kehm, R., Muranyi, W., Darai, G., 2005. New ecological aspects of hantavirus infection: a change of a paradigm and a challenge of prevention-a review. Vir. Gen. 30, 157180. 